\title{
Colonial Heritages, Educational Incompartibilities and the Challenges for a Reunified Cameroon: 1961-2016
}

\author{
ROLAND N. NDILLE*
}

Koloniální dědictví, vzdělávací neslučitelnost a další výzvy

pro opětovně sjednocený Kamerun: 1961-2016

\begin{abstract}
The reunification of British Southern Cameroons and La Republique du Cameroun 1961 required the adoption of new national policies which were to guarantee that none of the colonial identities were jeopardized. ${ }^{1}$ In doing this, the Federal Republic adopted harmonization as a policy framework for the establishment of a new national educational system that was to unequivocally represent both colonial heritages without feelings of marginalization by any side. Using archival evidence and some empirical literature, this paper has examined the landmark developments in the harmonization of education in the country. It has observed that although significant strides have been made there are still huge challenges. The paper concludes that until both sides are determined to put national interests above former colonial interests, harmonization and the ultimate establishment of a national educational system cannot be achieved. ${ }^{2}$
\end{abstract}

Keywords: Reunification of Cameroon; Harmonization of Education; British and French Colonial heritages; Incompatibilities

DOI: $10.14712 / 23363525.2020 .3$

\section{Introduction}

Between November 2016 and the time of writing this paper, the Anglophone regions (North West and South West) of Cameroon have experienced a series of socio-political upheavals which, except for the major towns, have led to what may be termed a complete shutdown of the educational and judicial sectors of the regions. Unfortunately these have degenerated into an armed secessionist movement. This is not unconnected to the issue of two colonial heritages (British and French Cameroons) coming into an established political entity in 1961 and the difficulties of managing the process of reform which was to take into consideration equity in representation of the erstwhile colonial identities within the union. Several studies exist on the history of education in Cameroon [Tchombe 2001] which provide an understanding of the educational background but in terms of the independent government policy-making by way of dealing with the two inherited systems and ensuring an egalitarian representation as policy required remains an outstanding challenge; reason why this historical analysis is undertaken.

* Roland Ndille N. (D.Litt et Phil.), School of Education, University of the Witwatersrand. E-mail: roland .ndille@ubuea.cm

1 Federal Republic of Cameroon [1961]. The Federal Constitution. Yaoundé: National Printing Press, p. 1.

2 The terms Anglophone and Francophone are used in the paper to represent the former British administered Southern Cameroons and French administered Cameroons respectively. 
As background, it is important to note that the question of British and French involvement in the German colony of Kamerun started in 1914 when as World War One allies, they invaded the territory in September and after obtaining a German surrender in February 1916, immediately went on to partition the territory. From April 1916, the territory was separately administered. In 1922, the two spheres became Mandates of the League of Nations and in 1946 - Trust territories of the United Nations. The final phase of the independence of the territory was achieved on October 1, 1961 when the British ended their trusteeship over Southern Cameroons. The territory had in a plebiscite organized on 11 February that year, voted to reunify with the French sector which had obtained independence on 1 January 1960 as La Republic du Cameroun. Reunification warranted the development of a concrete political and socio-economic frame work that would not only ensure the positive utilization of the gains from the two colonial systems but also guarantee the development of an authentic Cameroonian identity in various sectors of life. The case of how this played out in the educational sector is the core of this paper.

\section{British and French Colonial Education Policies: A Justification for Harmonization after Reunification}

Within the context of the history of Cameroon, an understanding of the colonial situation in the two spheres is imperative for a justification of difficulties that characterized the policy of harmonization of education adopted in 1961. Several studies have been undertaken in that direction [Ndille 2018; Tamanji 2011; DeKorne 2012]. However, it is important to state that as far as education was concerned, the British and the French administering authorities had operated two systems of education distinct in policy, structure and contents which had serious implications for the establishment of a harmonized national education policy. Table 1 below is a summary some of the characteristics what each side brought to the reunification table in terms of educational policy and practice. It shows how differences in policy gave rise to different structural and curricula orientations and how the various sectors' desire to each guarantee that theirs was preserved in the attempts to establish a harmonized system of education were to pose huge challenges in the educational reform process.

Table 1 demonstrates that the English and French speaking Cameroonians by their training were two different people who had to put in a lot or give away so much to enable reunification of education to succeed. For example, the different durations of school courses demonstrated that by the time candidates got their high school certificates and were vying for employment or admission into the university, everything being equal, those educated in the Anglophone system would be more than three years older than their francophone counterparts. This was a serious problem in a reunified Cameroon where age limits were placed on competitive entrance examinations into most professional schools. In this regard the candidates from West Cameroon were seriously disadvantaged. The same applied for curriculum and end of course examinations, certificates and school structures where emphasis in the colonial period had been placed on British and French civilizations. 
Table 1: The nature of the two inherited colonial school systems prior to independence

\begin{tabular}{|l|l|l|}
\hline \multicolumn{1}{|c|}{ Aspect to be harmonized } & British Southern Cameroon & La Republique du Cameroon \\
\hline Entry age into nursery school & 3 years & 4 years \\
\hline Entry into primary school & 5 years & 6 years \\
\hline Duration of primary school & 8 years & 6 years \\
\hline $\begin{array}{l}\text { Expected Primary School } \\
\text { leaving age }\end{array}$ & 13 years & 10 years \\
\hline Certificate offered & FSLC & CEPE \\
\hline Duration of secondary school & 5 years & 4 years \\
\hline Secondary school certificate & GCE O/L & BEPC \\
\hline Duration of High school & 2 years & 3 years \\
\hline High school certificate & GCE A/L & Baccalaureate \\
\hline Education structure & Decentralized & Centralized \\
\hline Education policy & Indigenous needs & Assimilationist \\
\hline Language policy & In favour of local languages & $\begin{array}{l}\text { In favour of Colonial language } \\
\text { (French) }\end{array}$ \\
\hline $\begin{array}{l}\text { State of secondary education } \\
\text { at independence }\end{array}$ & $\begin{array}{l}\text { Un-prioritized by colonial } \\
\text { government }\end{array}$ & $\begin{array}{l}\text { A colonial government } \\
\text { priority }\end{array}$ \\
\hline $\begin{array}{l}\text { Attitude towards technical and } \\
\text { vocational education }\end{array}$ & Negligent & Positive \\
\hline Policy on school fees & $\begin{array}{l}\text { Compulsory fee paying } \\
\text { system with few scholarships }\end{array}$ & $\begin{array}{l}\text { Free education and } \\
\text { scholarships }\end{array}$ \\
\hline On the training of chiefs & No schools available & Special schools available \\
\hline
\end{tabular}

Source: Author's Analysis

Reunification therefore imposed on the new state an urgent need to restructure education in a way that will ensure that one colonial system does not dominate the other; that will beset the various state and cultural affiliations and most especially develop into a unique and authentic system of education to inspire a sense of adherence to a single Cameroonian identity. This was not to be any easy task.

\section{Harmonization as Cameroon's Official Education Policy at Reunification in 1961}

Reforms in any system strive to accommodate social, political, economic and technological developments as a function of historical change. Such reforms necessitate the re-adaptation of social services and their institutions, so as to enable people meet with demands of the changing times. In education, the concept of reform as it was engaged by newly independent states reflects ideological, policy, administrative, structural, curricula, pedagogical and system evaluation initiation, restructuring, or adjustments aimed at correcting previous deficiencies or improving the present context. The need for such reforms 
becomes even dire in the context where two or more formerly autonomous states come together to form a new state or supra-state structure.

In Cameroon, the federal government which was established following reunification amongst other policy imperatives adopted harmonization [Federal Republic of Cameroon 1963]. Conceptually, it implies the coming together of two previously autonomous systems, the dissolution or blending of their systems for the purpose of establishing one common system that would foster unity in all facets of life. It is often expected that those establishing the union would set up one central system which would not divide the allegiance of the citizens. In this way the new system would not permit the continued loyalty to the erstwhile regions or systems because such an allegiance is apt to breed discordance and separatist tendencies among the constituent units [Amal - Bhattacharya 2005]. Brief, the members of the reunified state are expected to prepare and embrace a totally new system which although picking up good qualities from the old systems is thought to be completely different from them.

In terms of service delivery and structure the new harmonized system should go a long way to meeting the demands of the reunified entities better than any of the previous systems. Thus the establishment of a new system becomes the ultimate fall out of harmonization. This is what is called the homogenization or the synchronization of previously autonomous, functionally different systems, in favour of a system having a unique national character [Hoosen et al. 2009]. Areas of attention often include; national goals and philosophies of education, curriculum content, educational structures, policies, legal frameworks, examination regulations, organization and certification, quality assurance and control.

In some parts of the world, harmonization has been a socio-political and economic option that has occasioned complicated but realistic processes of structural reforms. Most importantly, it has inspired a radical transformation of educational systems aimed at meeting the goals for which the stakeholders concerned had opted for it. Apart from emphasizing the extension of educational opportunities to the entire population in the union alongside manpower development, the forging of a greater level of unity of the constituent parts of the union, the need to guarantee equity and unanimity has also been a major preoccupation of harmonization. Through innovative forms of collaboration amongst the various stakeholders in the union, education can systematically be improved against common agreed benchmarks of excellence, thereby facilitating the mobility of students and teachers across the cultures being harmonized. The aim is to have similar programmes, structures and curricula for enhancement of a productive and creative human resource for the united socio-political systems [Tchombe 2001].

Harmonization of education may not have been peculiar to a reunified Cameroon after 1961. In Germany, the vast differences between the former East-Germany and West Germany in life style, wealth, political belief, education and other values have warranted politicians and scholars to call for harmonization after 1990. It has also gone beyond national to supra-state concerns as most regional blocs call for greater and more cohesive regional integration policies. In the European Union for example harmonization of school programmes, certificates and structures has long been a matter of EU policy [Ravioli 2009]. The Bologna Process is an ongoing process of integration and harmonization of higher education systems within Europe. Its conceptual framework and action lines have the ultimate objective of establishing a European Higher Education Area (EHEA), 
where harmonization of academic degrees and quality assurance practices are guaranteed [ibid.].

In East Africa article five of the treaty of the establishment of the East African Community Education [East African Community 2012] clearly states that in order to promote the achievements of the objectives of the community, partner states agree to undertake concerted measures to foster cooperation in education and training within the community. Apart from agreeing to co-ordinate their human resources, develop programmes and policies, the member states have agreed to also harmonize curricula, examinations, certification, and accreditation and training institutions through the joint action of their relevant national bodies in charge [ibid.]. In this region since 1998, harmonization has moved from theory to practice as the states concerned have actually integrated or harmonized the provision and training services through unique curricula and established regional organizations and institutions such as the East African National Educational Council. Although for this case unity of curricula is still in progress, the treaty setting up the East Africa Community Education noted that it would be preposterous to completely rule out uniformity in this regard (as per the working definition of harmonization). Consequently, the target is the adoption of a common school structure and programmes for the whole region in the near future.

In contemplating harmonization in Cameroon after reunification, UNESCO identified three possibilities [Tambo 2000]. The first option was for the various stakeholders to adopt the system in place in one of the member states seen as more proficient and or efficient. This option was however not likely to be adopted as none of the parties was likely to give up their system for fear of cultural dominance. The second option was for the parties to run the same programmes in their various languages and spheres after agreed upon structures and policies. The third option was that a completely new system could be introduced beginning with the lowest class or level and continuing year by year until an entirely new local system comes into being [UNESCO 1962]. The EU and the East African Community mentioned above seem to have adopted the second option by establishing an increasingly networked and interrelated group of curriculum and examination systems, linked in a way that demonstrate overlapping, inter-connected and comparable logics that are capable of influencing each other across the partner states. Within the Cameroon case, the question which needs to be answered is whether, of the three approaches, there was an officially agreed upon framework and whether the implementation of that framework posed any challenges to equitable educational acquisition in the two reunified states.

\section{Efforts and Challenges in the Harmonization of Education in Cameroon 1961-2016}

Since reunification in 1961, one of the many problems that have plagued the nation was how to cope with the incongruous and somewhat incompatible British and French inherited systems of education. A UNESCO mission visited the country between March 10th and May 20th 1962 to study the educational problems that the young nation was facing and to suggest solutions that could be used to have a uniform system of education [ibid]. A follow up mission arrived the country in September 1963 and stayed on till December that year [UNESCO 1963]. After a careful study of the situation in West (former British) and East (former French) Cameroons, the missions made three proposals for the harmonization of 
education in Cameroon. As we would come to find out below, the first option was overtly rejected and as a matter of policy what the new state opted for was an unrealistic blend of UNESCO's second and third options. In fact one could rightly say that based on later developments it is unclear which of the options the stakeholders adopted.

Following the release of UNESCO's 1962 report, a series of laws were passed geared towards tackling the problem of harmonization of education amongst other things. The Federal Government issued Federal law No.1.63/DF/13 of 19 June 1963; on the organization of secondary general and technical education [Federation of Cameroon 1963]. The East Cameroon State Government issued law No. 1.63/COR-5, of July 1963 on the organization of primary education in the state of East Cameroon [East Cameroon 1963] and the West Cameroon State Government responded with the West Cameroon Education Ordinance in the same month [West Cameroon 1963]. Regarding harmonization, the West Cameroon Education Ordinance stated inter alia that "unification implies a unified system of education" and went on to emphasize that;

for this reason government does not object to, and in fact welcomes such measures as will promote a unity of the two structures of education. The length of courses, the beginning and ending of the academic year, the dates of holidays (even the basic aims of education in the context of the Federal Republic) all these and other structural details can easily and should be harmonized. [East Cameroon 1963: 3]

The same policy anticipated that the academic year will in future begin in September and end in June, to harmonize with secondary school and university terms. This was to be achieved by September, 1964. With the coming of reunification, the state ministries of education and social welfare were in charge of only primary education. Secondary schools in Anglophone Cameroon which had come under the federal ministry had already adopted the September-June academic year as was applicable in the Francophone sector.

To harmonize the duration of primary education which was within the jurisdiction of the state ministries of education, the West Cameroon state government proposed in the 1963 Ordinance that the primary school academic course will be reduced to seven years from 1963 and to six years from 1965, again, to harmonize with the practice in the French speaking zone. For secondary schools which were under the auspices of the Federal Government, the federal law No.1. 63/13 of 19 June 1963 stated that studies in secondary general education schools would last five years. Complete high schools or lycees (those that combined secondary and high school sections) would last seven years comprising a five year first/secondary cycle and a two year second/high cycle. This was one of the aspects of the law that seemed to have adopted the system in operation in Anglophone Cameroon. By the decree, it was expected to become effective from 1965 .

The west Cameroon government went on to effectively implement its 1963 education ordinance by reducing its eight years primary education by one year in 1964 and was looking forward to reducing it further to six in the subsequent year. This did not happen probably because the francophone region failed to implement the restructuring of its four-three years secondary and high school structure to the five-two years' structure as the case in Anglophone Cameroon. In matters of curriculum harmonization, all the laws were silent. The west Cameroon law however mentioned the teaching of French in their sector. 
In 1965 there were some developments at the federal level which many thought would lead to the development of a harmonized national system of education. That year, the Higher Council for Education requested for the harmonization of structures and curricula of secondary education in the two federated states by creating a Joint Committee of Experts. Members were to come from both federated states and were to examine the secondary school syllabuses and examination systems with a view of harmonizing them [Federal Republic of Cameroon 1965]. Following these guidelines, the Committee for the Harmonization of Education in the Republic met in Yaoundé from January 13th to January 15th 1966. In this meeting the Minister of National Education William Eteki Mboumoua explained that the government;

aims at providing the same content of education to all Cameroonians no matter where they were situated in the nation $[\ldots]$ to determine examinations to be done on the national level [...] since the education was to be Cameroonian in content and spirit. (The committee of experts was) to select from both systems what was valuable, enriching and educationally good, and which would provide a recognized standard. [Federal Republic of Cameroon 1966: 2]

The committee recommended that the GCE Ordinary Level of West Cameroon and the Brevet d'Etude du Premier Cycle (BEPC) of East Cameroon should be replaced by a single certificate called the Certificate of General Education (CGE) while the GCE Advanced Level and the Baccalaureate be replaced by the Secondary Education Leaving Certificate (SELC). Candidates to these exams were to study the same subjects and content although in their respective first official languages (English or French). With these proposals the Commission demonstrated that harmonization could in effect take place if the will was there. Their proposals painted a positive picture around the country and hopes of having an indigenous national education structure, curricula and examination were beginning to be realized. They demonstrated that experts were ready to do the groundwork and ensure implementation and that it was only the political will that was left to complete the process. In 1968, the Committee met in Douala to propose new syllabuses and in 1971 they met again in Yaoundé to put finishing touches. Their work was only waiting final approval from the Higher Council of Education [Ministry of National Education 1985]. This final approval was never obtained and these efforts have since been dashed into thin air.

In 1972, rather than following up the recommendations and proposals of the Committee for the Harmonization of Education in the Republic, the government set up the Institute of National Education (INE) in Yaoundé by presidential order No.1. CMR/72/018. The Institute had as mission to undertake research aimed at implementing a harmonized education system and making policy recommendation to the Minister of National Education [ibid.]. It was hoped that the creation of the Institute would speed up both structural and curriculum harmonization. By another decree of September 1973, the president spelt out their functions which seem to duplicate the functions of the Committee created in 1965. They were to carryout research in secondary education with a view of harmonizing or improving the proposed secondary school syllabuses. Pretesting of the mathematics, civics, history and geography programmes was to be carried out at the Bilingual Grammar School Molyko, in Buea. Textbooks to this effect were also to be written. Again, like the proposals of the 1965 Committee, very little was heard of the activities of INE in terms of 
achieving their goals. Education in the country continued to reflect the inherited colonial systems which each side brought to the reunification table.

In 1977, both the General Certificate of Education (GCE) Advanced Level and Ordinary Level were nationalized. Until then, this secondary education end of course(s) examination for the Anglophone sub-system of education was managed and organized by the University of London. The move from what was popularly known as the London GCE to a national GCE was seen as a positive step towards harmonizing examinations and certifications. However, what ensued demonstrated more overt signs of assimilation of the Anglophone certificate to the French system. Instead of establishing an Examination Board, the Ministry of National Education took over the setting, administration and the award of GCE certificates. As London officials gradually withdrew, the exams began experiencing irregularities. In 1990 the London University Examination Board relegated its former role on the Cameroon GCE, as irregularities had reached an alarming rate [Ndongko - Nyamnjoh 2000].

In 1983 the government in a ministerial order dated 27 September, 1983, instituted the "Group Certificate Scheme" in the GCE. This was to convert the single certificate examination to a group certificate exam from 1985 for the Ordinary Level and 1987 for the Advanced Level [Republic of Cameroo, 1984: 87]. In this new situation, an aggregate performance in a specific number and range of subjects was to be established and a pass in some compulsory subjects (French, English and Mathematics) was required to qualify for the award of the certificate. It is reported that the Minister of National Education who made this proposal Rene Ze Nguele justified it with the fact that Anglophones were not doing enough to be bilingual and that they were doing very poorly in science oriented subjects. He lamented that there were very few Anglophones in science oriented professional schools like the National Advanced School of Engineering, the Institute of Demography in Yaoundé and the University Centres of Ngaoundere, Douala and Dschang. Even in the Departments of Mathematics and Physics of the then University of Yaoundé, the rate of failure for Anglophones was said to be very alarming [Ngoh 1987].

The implication of the ministerial circular was that, the GCE had to take the same orientation as examinations in the Francophone sub-system of education. With the failure to reform the francophone secondary educational structure in the 1960s as was required by law to suit that in the Anglophone Subsystem; and after conceding to reforming primary education to suit the practice in the Francophone sub-system, the Anglophones began to view efforts such as proposed by the Ministerial circular within the context of marginalization and attempts to neutralize their educational heritage. The proposals were rejected in a series of demonstrations by Anglophones in Yaoundé and in the Northwest and Southwest provinces. The students wrote to the Head of State demanding the annulment of the New GCE reform because according to them, the group certificate was naive, over demanding and too rigorous.

According to the striking students, the reforms confused quantity with intensity by imagining that the more the papers taken at ' $\mathrm{A}$ ' level, the better the chances of the candidate in higher institutions. The students argued that if Anglophones were under-represented in professional schools and institutions of higher education, the fault was not the GCE or the Anglophone educational system, but rather, the fact that these institutions were designed to answer more to the needs of those with the Baccalaureate than to the needs of candidates 
with the GCE. In Bamenda, teachers, students and some parents marched from the commercial avenue to the up-station Mendakwe office of Governor David Abouem a Choyi to present their petition against the Yaoundé decision.

The Anglophones also saw the reforms as a prelude to the abandoning of the GCE for a translated version of the BEPC and the Baccalaureate [Achombang 2010]. The president's response through the Speaker of the National Assembly on 2 December 1983 was that the striking students should return to class [Nyamnjoh 2000]. The students' protests however achieved some results. The plan was temporarily shelved and a Presidential Commission was formed which travelled to Canada, Britain, West Africa and throughout the country to inform itself on similar traditions and practices. However, their findings which were supposed to be urgent, are yet to constitute a report.

In 1989 another Minister of National Education George Ngango, instead of initiating the 1963 harmonization laws with the implementation of the five-two year's system of secondary education in the Francophone region, introduced another ministerial package which would have imposed the Francophone four-three year's system on Anglophone Cameroon. This reform never took place because of the fierce opposition and demonstrations by Anglophone students and their parents. Coupled with the 1983 proposals, and the lukewarm attitude of the mostly Francophone led Ministry of National Education to implement the 1963 reform of secondary education, this second package of reforms demonstrated that the state had abandoned the harmonization laws and was proceeding with the assimilation of the Anglophone system into that of the Francophones as had been the case with many economic and political structures. This move embarrassed the Anglophones, questioned the sincerity of reunification and completely led to their loss of confidence in the francophone led government. Again protests were planned but were nipped in the bud probably by the removal from office of the said minister as he was closing a seminar [Tatangang 2011].

One of the efforts at harmonizing school programmes in Cameroon led to the introduction of Manual Labour in the Francophone region in 1967 to match with the programme in west Cameroon. The government created IPAR in Yaoundé (for the Francophone school system in 1967) and IPAR in Buea (for the Anglophone schools in 1974). In the Francophone sub-system, this was not loved by the pupils as well as teachers and was implemented with little enthusiasm. Because of such reluctance IPAR produced programmes and syllabuses which were never put into use. Such programmes would have formed the basis for the harmonization of primary education in the entire country. The IPAR projects were long abandoned in the mid-1980s [Ndille 2015].

In the area of technical and teacher education the situation has been less antagonistic. In technical schools, there has been no problem as the technical schools in Anglophone Cameroon have been operating the same syllabuses and structure with those in Francophone Cameroon. The Francophone four-seven years structure and their technical school examination/certificates have since reunification been extended to Anglophone Cameroon; the Certificat d'Aptitude Professionelle (CAP) after the first cycle of four years and the Baccalaureate Technique (BAC) after the second cycle of three years. This was probably because since reunification technical education has been managed by the federal government rather than foreign examination boards as was the case with the GCE. 
As far as teacher training was concerned, the Anglophone and Francophone sectors carried out different practices in terms of entry requirements, structure, syllabus, duration and certificates of teacher training colleges. But governments attempt to increase teacher population all over the country motivated them to reorganize and harmonize practice in the sector in the 1980s. It opened two types of training institutions in all provinces; Ecole Normale d'Institutuer (Grade I teacher colleges) and Ecole Normale d'Instituteur Adjoint (Grade II teacher colleges) (Tchombe 2001]. These were further reformed in the 1990s when the Grade II class was abolished. All aspiring teachers had to go in for the Grade I programme now called the Certificat d'Aptitude Professionelle d'Instituteurs Martenelles et Primaires (CAPIEMP) although the duration differed depending on the entry qualification. Here again, like technical education, the structure reflects more the system which was in place in Francophone Cameroon; a re-introduction of the practice of teacher training in colonial French Cameroon and thus, another instance of assimilation of the Anglophone system which had operated a five year technical college at Ombe in the 1950s.

As far as secondary school teacher training is concerned, there was no practical experience in Anglophone Cameroon before reunification apart from the Cameroon College of Arts and Science, Bambili. This gave the government the free hand to extend the system in place in French Cameroon on the Anglophone Cameroonians. The Ecole Normale Superieur (ENS) in Yaoundé with mostly Francophone teachers and administrators set up a branch in Bambili (a town in Anglophone Cameroon) for the training of secondary school teachers of the English subsystem. Again the structure, language of instruction, curriculum as well as the certificates were predominantly French styled. Till date the names of the schools as well as the certificates are solely known by their French appellations.

In 1995 an educational forum was organized in Yaounde by Minister Robert Mbella Mbappe. This forum aimed at establishing a new orientation of the educational system and its proposals were to lead to a new law of education which was imperative considering the fact that since reunification a comprehensive law covering all facets of education had not been established. It was expected that this forum would reopen the debate on harmonization but the twelve-point rationale for the convening of the conference, was basically silent on the matter [MINEDUC 1995]. Issues discussed included, the aims of education, pedagogy, administration and management of educational resources.

Sadly too, the 1998 law that ensued from the 1995 forum's recommendations seem to have put a final nail on harmonization by acknowledging that Cameroon shall run two subsystems; English speaking and French speaking subsystems. At the primary level coordinated efforts to ensure that practice remains the same in the two subsystems have resulted in a common syllabus document published in 2001. At the secondary level where the structure is still different and two examination boards exist since 1993, (the Cameroon GCE Board at Buea and the Office du Baccalaureate at Yaounde) the two subsystems have become even more glued to those of their respective colonial metropoles.

At the level of the universities harmonization was not a call for concern as the system has since reunification been structured on the French University lines in the then only Federal University of Cameroon in Yaoundé. This posed serious problems for most English speaking students who entered the University and its affiliated higher and professional educational institutions until the creation of the University of Buea in 1993. The creation of Buea as an Anglo-Saxon university brought in the English University system which 
operated parallel to the French system in the other universities which were created alongside. Once more this was a departure from harmonization of Higher Education. At inception, the Anglo-Saxon university at Buea operated a Bachelor, Master, Doctorate system on a 3-2-3 year basis with one-year Post-Graduate Diplomas (PGD) in some programmes. The other universities (all located in the Francophone sector of the country) operated in the French university culture. They offered a Licence, Maitrise, Diplome d'Etude Approfondie, Doctorat de 3eme Cycle and Doctorat d'Etat on a 3-1-1-3-3 year basis.

However, as from 2007, the university certificates have since been harmonized and the Bachelor, Master, Doctorate (BMD) system is currently being adopted by most universities although in matters of programmes and course contents, the universities act independently. Recent efforts to harmonize university programmes especially in the classical programmes have been resisted. Anglophone academics have seen these as another means to spread the Francophone influence over the Anglophones. There are plans that similar contents and programmes should be established in all the state universities, if not for other reasons but to facilitate mobility of students and lecturers. Some programmes like the English common law have been introduced in the Francophone Universities while a French Civil law department has been opened at the Anglophone University of Buea. These efforts are limited if considered within the context of the harmonization of the university system in Cameroon.

\section{Harmonization of Education in Cameroon: Achievements, Challenges and Prospects}

To what extent has harmonization been achieved in the field of education since the passing of the decrees on harmonization in 1963? Have we succeeded in developing the much desired unique national education culture or do we simply co-exist? An examination of the efforts of harmonization demonstrates a picture of confusion, lack of will and an obstinate desire to cling to colonial set values. An interpretation of the 1963 laws on the harmonization of education indicates that in principle, primary and secondary education should have been structurally harmonized by 1965 if the will was there. As from 1965, West Cameroon was to operate a six years primary school course to correspond to the six years primary education system in the East Cameroon. East Cameroon should have also adjusted its secondary school course to five years from four. Alternatively, a middle road situation would have been sought as advised by UNESCO's third option.

A careful examination of the present state of education demonstrates some successes as well as some loop holes. At the primary level, the six year course has been adopted in both sectors since 2007. Although the names of the certificates differ, the syllabuses have also been harmonized. This took the Anglophones the last nerve to give up their inherited system to adopt what was in place in the French subsystem. At the secondary level, it has not been a similar picture. The Francophones were expected to adopt the 5-2 year school structure of the Anglophones in 1965. This is yet to be effected. Added to that, the French sub-system runs an exam in the sixth year, the Probatoire, which doesn't exist in the Anglophone General Education sub-sector. Besides, the creation of separate examination boards has made harmonization even more farfetched in secondary education. The exams have very little of semblance in organization, setting and content. At the level of the universities, the creation of the Anglo-Saxon University of Buea and 
recently, The University of Bamenda, has further legitimated the dual university system in the country and exacerbated dreams of a harmonized university system in Cameroon. Although the BMD programme seems to be an effort to harmonize the structure of higher education, the two systems have clung stubbornly to their colonial metropolitan types of universities.

The differences that are still characteristic of the two subsystems of education in Cameroon demonstrate that harmonization in terms of developing a unique Cameroonian school system is still a thing of the future. It shows that what exists now is a kind of co-existence. It is also important to note that the instances where harmonization has succeeded, it has taken the good will of the Anglophones to give into the francophone system. On the other hand where harmonization has failed, it has been in cases where the Francophone led government has not been willing to implement the Anglophone structures as was initially previewed in the 1963 policy documents. With the exception of Higher Education, there has been no Minister of National Education of Anglophone background in Cameroon until the appointment of Nalova Lyonga in early 2018. This has rather justified Anglophone skepticisms and the many suspicions of assimilation that sparked the demonstrations of the 1980s, 1990s and the civil unrest that started in November 2016. It is for this reason that no policy in this regard has succeeded to go through without being taxed by Anglophones [Tatangang 2011].

Apart from situations of mutual suspicion and reluctance, many more reasons have been advanced for the slow pace of harmonization in the country. Some hold that although many proposals were worked out on the principle of harmonization, they were, owing to political reasons as well as the lack of technical and financial resources, never implemented. Others allude this failure less to the absence of political will and more to the absence of proper research in this domain and the stubborn adherence to inherited colonial subsystems [Ngalim 2014]. What then is the future of harmonization in the country? First it requires the state's determination to establish a policy of education in which none of the heritages would feel marginalized or assimilated. Second, experts need to study the situation and decide which of the options would be most suitable for Cameroon. Thereafter they must set up a framework for operation which should become law binding on all sectors. After this a time-line for the implementation of the policy must be published marking specific deadlines and finally, resources must be made available for implementation, monitoring and evaluation of such a programme.

When this is done, a major difficulty that needs to be addressed for harmonization to take effect is that leaders need to shake off the colonial yoke acquired through their own colonial education. This is a major impediment to the development of national policies in Africa. Through colonial education Cameroonian intellectuals and academics on both sides reached a point of total estrangement from local conditions and ways of life. That is why as Grosfoguel has argued, even from this [global south] oppressed side they continue to think and speak epistemologically and linguistically like the Euro-American intellectuals and academics on the dominant side [Grosfoguel 2011]. What was therefore expected to be a revised postcolonial educational system simply is not far from a replica of the colonial imperial one over fifty years after independence. This is what is meant by the African crisis of a lack of essence [Mignolo 1998] and by coloniality being the "reproduction of obsequiousness joined by local actors" [Ndlovu-Gatsheni 2013: 5]. 
Of course, a cloud of doubt had long been cast on those who went through the colonial school in terms of their being able to deliver on independence and indigenous reform. Writing in 1963, a few years into the wind of change, Franz Fanon, could already see that precisely because they had totally assimilated colonialist thought in its most corrupt form, the innermost vocation of those who passed through the colonial school would never be to transform the countries [Fanon 1963]. In their search for legitimation to play among the club of international independent states, the elites would rather sustain the reproduction of imported epistemological locations which they had acquired in their colonial school days.

The attitude towards harmonization of education in Cameroon and the challenges in its way are therefore significant factors of the outcomes of educational provision in both spheres of the Cameroons. Besides, attempts at harmonizing two distinct educational cultures in an atmosphere plaqued by a strong affiliation to the colonial cultures seem illusive especially in the context of British and French colonial ideologies which seem somewhat incompatible. While Britain's colonial ideology reflected a strong undercurrent in cultural relativism; a human interest in the native people, the French model on the other hand corresponded more closely with the idea of cultural universalism [White 1996] which sought to bring dependent ethnic groups together under one roof and unify them through French Language and culture. There was therefore a kind of British centrifugal system as opposed to a French centripetal system which justified not only the mindset of the people who emerged from the colonial territories but also accounted for their perspectives of what a country should be and the kind of state they were looking forward to build for their people.

\section{Conclusion}

The paper has demonstrated that so far the reunified state of Cameroon is still to develop a uniquely Cameroonian educational system. The current structure is not in line with any of the three options proposed in 1962-3. While structural harmonization has been achieved in primary education, secondary and higher education continue to be attuned to inherited colonial systems. The process has been wrought by the absence of implementation resolve on the part of the majority Francophone led governments. Visible efforts suggest a seeming preference of Francophone values over those of the Anglophone heritage which have led to suspicion, feelings of assimilation/neutralization and ultimately, resistance on the part of the minority Anglophones. The paper concludes that until both sides are determined to put national interests above former colonial interests, harmonization and the ultimate establishment of a national educational system would continue to be a slippery ground to walk on. Proposals, policies and recommendations for a harmonized system of education must be adopted because of their effectiveness in terms of global trends and not because they represent a particular colonial heritage that must be preserved.

\section{Bibliography}

Achobang, Christopher [2010]. Decolonize the Mount Cameroun Race. Prince Report online Newsletter. Retrieved from: <http://princereport.blogspot.com/2010/02/decolonize-of-mount-cameroon-race .html>.

Amal, Ray - Mohit, Bhattacharya [2005]. Political Theory: Ideas and institutions. Kolkata: World Press. 
DeKorne, Helen [2012]. The Builders of Identity: Education, Language and the Elites of Cameroon 19161961. Unpublished BA (hons) Thesis Wesleyan University, Connecticut.

East African Community [2012]. Regional Report: Harmonisation of the East African Education Systems \& Training Curricula.

East Cameroon [1963]. Loi No. 1.63/COR-5, du Juillet 1963 Portant Organization de L'Enseignement Primaire Elementaire. Yaounde: Journal Officiel de L'Etat du Cameroun Oriental.

Federal Republic of Cameroon [1961]. The Federal Constitution. Yaounde: National Printing Press, p. 1.

Federal Republic of Cameroon [1963]. Law No. 63/DF/13 of 19 June 1963 on the Harmonization of Educational Structures in the Federal Republic of Cameroon. National Archives Buea (NAB).

Federal Republic of Cameroon [1965]. Higher Council of Education Guidelines on the Harmonization of Education in the entire Extant of the Federation. Yaoundé: HCE.

Federal Republic of Cameroon [1966]. Report on the Educational Meeting in Yaoundé to Harmonize Syllabuses and Examinations, January 13-15, 1966. Yaoundé: HCE.

Franz, Fanon [1963]. The Wretched of the Earth. Middlesex, England: Penguin Books.

Gwei, Solomon Nfor [1975]. Education in Cameroon: Western Precolonial and colonial antecedents and the development of Higher Education. $\mathrm{PhD}$ thesis University of Michigan.

Hoosen, Sarah - Butcher, Neil - Khamati Njenga, Beatrice [2009]. Harmonization of Higher Education Programmes: A Strategy for the African Union. Africa Integration Review 3 (1): 3-18.

Ministry of National Education (MINEDUC) [1985]. La Reforme de L'Enseignment Au Cameroun: Bilan 1967-1985 et strategies de Relance. Yaounde: National Centre of Education (NCE).

Ndille, Roland [2015]. From Adaptation to Ruralization of Education in Cameroon: Replacing Six with Half a Dozen. African Educational Research Journal 3 (3): 153-160.

Ndille, Roland [2018]. British and French Implementation of Colonial Education Policy in Cameroon: A Comparative Analysis. International Journal of Research in Educational Studies 4 (5): 1-18.

Ndongko, Therese - Nyamnjoh, Francis [2000]. The Cameroon General Certificate of Examination Board. In. Ndongko, Therese - Tambo, Leke (eds.). Educational Development in Cameroon 1961-1999. Platville, MD: Nkemnji Global Tech, pp. 246-257.

Ngalim, Valentine [2014]. Harmonization of the Educational Subsystems of Cameroon: A Multi cultural perspective for Democratic Education. Creative Education 5 (5): 332-346.

Ngoh, Victor-Julius [1987]. Cameroon 1884 to 1985: A Hundred Years of History. Limbe: Navi-Group Publishers.

Ramon, Grosfoguel [2007]. The Epistemic Decolonial Turn: Beyond Political Economy Paradigms. Cultural Studies 21 (2-3): 211-223.

Ravioli, Simone [2009]. Harmonizing Higher Education: Standard Perspectives in Support of the Bologna Process. Akademik Bilişim Harran Üniversitesi 11 (0): 1-13.

Republic of Cameroon [1984]. Ministry of National Education, Inspectorate General of Pedagogy Annual Report for 1984.

Sabelo, Ndlovu-Gatsheni [2013]. Coloniality of Power in Postcolonial Africa: Myths of Decolonization. Dakar: CODESRIA.

Tamanji, Asanji [2011]. Three Instances of Western Colonial Governments and Christian Missions in Cameroon Education: 1884-1961. PhD Thesis, Loyola University, Chicago.

Tambo, Leke [2000]. Strategic concerns in Curriculum Development in Cameroon. In. Ndongko, Therese Tambo, Leke (eds.). Educational Development in Cameroon 1961-1999. Platville, MD: Nkemnji Global Tech.

Tatangang, Henry [2011]. Education, training and Employment: the key to Africa's development in the era of globalization. New York: Xlibis

Tchombe, Therese [2001]. Structural reforms in Education in Cameroon. Conference Paper, University of Yaoundé 1 School of education.

Theresia, Ndongko - Leke, Tambo [2000]. Educational Development in Cameroon 1961-1999. Platteville MD: Nkenmji Global Tech.

UNESCO [1962]. Cameroonian Education Planning Group. Report Drawn up on the Return of the First Mission 10 March to 20 May 1962. Paris: UNESCO;

UNESCO [1963]. Emergency Programme for Africa: Cameroon Second Mission of the Education Planning Group September to December 1963. Paris: UNESCO. 
Walter, Mignolo [1998]. The Darker Side of the Renaissance. Ann Arbor: University of Michigan Press. West Cameroon [1963]. West Cameroon Education Ordinance. Buea: Government Printers.

White, Bob [1996]. Talk about School: Education and the colonial Project in French and British Africa (1860-1960). Comparative Education 32 (1): 9-26.

Dr. Roland Ndille holds a BA (Hons) degree in History and Political Science, a PGDE and M.Ed in Curriculum Studies and Teaching from the University of Buea-Cameroon. He also holds a Master of Arts in African Studies from Dalarna University in Sweden and a Doctor of Literature and Philosophy (D.Litt et Phil) from the University of South Africa (UNISA-Pretoria) in History with research interest in Decoloniality, History and Policy of Education. He is currently a Post-Doctorate Research Fellow (PDRF) at the Centre for Education Rights and Transformation (CERT) Faculty of Education, University of Johannesburg. Dr. Ndille has been Head of the History Department (2015-17) and Head of Service for Teaching and Research (TRS), Faculty of Arts at the University of Buea-Cameroon. 